\title{
Correlation and heritability analysis in rapeseed (Brassica napus L.) genotypes
}

\author{
Keenjhar Laghari ${ }^{1}$, Munaiza Baloch ${ }^{1}$, Jay Kumar Sootaher ${ }^{1 *}$, Kirshan \\ Kumar Menghwar ${ }^{1}$, Mitho Kachi ${ }^{1}$,Zeeshan Majeed Kumbhar ${ }^{1}$, Waqar \\ Hussain Shah ${ }^{2}$, Mukesh Kumar Soothar ${ }^{2}$ and Irfanullah Daudpotto ${ }^{1}$ \\ 1. Department of Plant Breeding and Genetics, Sindh Agriculture University, Tandojam, Sindh-Pakistan \\ 2. Department of Soil Science, Sindh Agriculture University, Tandojam, Sindh-Pakistan \\ *Corresponding author's email: jaykumar3030@gmail.com \\ Citation \\ Keenjhar Laghari, Munaiza Baloch, Jay Kumar Sootaher, Kirshan Kumar Menghwar, Mitho Kachi, Zeeshan \\ Majeed Kumbhar, Waqar Hussain Shah, Mukesh Kumar Soothar and Irfanullah Daudpotto. Correlation and \\ heritability analysis in rapeseed (Brassica napus L.) genotypes. Pure and Applied Biology. Vol. 9, Issue 1, \\ pp507-516. http://dx.doi.org/10.19045/bspab.2020.90056

\begin{tabular}{llll}
\hline \hline Received: 24/08/2019 & Revised: 25/10/2019 & Accepted: 07/11/2019 & Online First: 05/12/2019 \\
\hline
\end{tabular}

\section{Abstract}

This investigation was made to find out new discoveries from the correlation and heritability for ten yield and participating attributes in eight rapeseed genotypes at the experimental field of Oil Seeds Section, Agriculture Research Institute, Tandojam during 2017-18 in a randomized complete block design entailing three replications. The analysis of variance articulated highly significant and significant differences for all the growth and yield supporting attributes. In case of correlation study, plant height showed positive and significant relationship with seed yield plant ${ }^{-1}$. Days to $75 \%$ flowering was non-significantly positive correlated with seed yield plant ${ }^{-1}$. There existed positive and significant correlation of number of siliquas of plant $^{-1}$ with seed yield plant ${ }^{-1}$. The associations of number of seed siliqua ${ }^{-1}$ were noted significant and positive with seed yield plant $^{-1}$. There was noticed positive and significant association of number of branches plant ${ }^{-1}$ with seed yield plant ${ }^{-1}$. Seed yield plant ${ }^{-1}$ was only positively as well as non-significantly correlated with seed yield acre ${ }^{-1}$. Seed index revealed positive correlations with oil content and seed yield acre ${ }^{-1}$. Higher estimates of heritability were unveiled for days to $75 \%$ flowering $\left(\mathrm{h}^{2}=89.94 \%\right)$, days to $75 \%$ siliqua formation, $\left(\mathrm{h}^{2}=\right.$ $96.77 \%)$, number of branches plant ${ }^{-1}\left(\mathrm{~h}^{2}=66.83 \%\right)$ and oil content $\left(\mathrm{h}^{2}=99.55 \%\right)$. It was concluded that in the existence of correlation, heritability can also be regarded quite imperative for the betterment of any polygenic attribute, nonetheless these genetic materials are preferred for further breeding programmes in the development of rapeseed genotypes in future.

Keywords: Correlation; Heritability; Rapeseed

\section{Introduction}

Rapeseed (Brassica napus) is grown primarily for its seed which yields about $40 \%$ oil and a high-protein feed for animals [1]. The crop rapeseed is an amphidiploid (AACC genome, $2 \mathrm{n}=38$ ) and it is said that it has originated from interspecific hybridization between diploid Brassica rapa $\mathrm{L}$. (AA genome, $2 \mathrm{n}=20$ ) and Brassica oleracea $\mathrm{L}$. (CC genome, $2 \mathrm{n}=18$ ) [2]. It mostly entails a lot of erucic acid which is slightly harmful to the mankind in high doses. Many things can be prepared from this crop such as lamp oils, plastics, soaps, lubricating oils and so on with the assistance of conventional and nonconventional methods. It has been confirmed by the European Union that, low amount of erucic acid and good composition of fatty acids in the edible oil 
of rapeseed makes it highly valuable in the world [3]. The local production of this crop during 2016-2017 was 179 thousand tons which was $3.2 \%$ lower than the previous year. [4].

Correlation is a statistical technique that can show how strongly pairs of variables are related. Among useful breeding characteristics, genotypic and phenotypic correlations are applied to determine the extent of correlation of certain yield contributing traits with their yield [5]. Phenotypic correlation coefficient of various grain yield and its components for its improvement of genotypic correlation coefficient has extensively studied $[6,7]$.

The phenotypic variability fraction of a character is measured and checked for attributable to genetic variation [8]. The extent of an attribute to which it is passed on from organism to the next in the form of heritability $[9,10]$. Genetic variation, nongenetic variation and random chance can all contribute to the expression of attributes in the body of an individual. High magnitude of heritability estimates exposes good genetic relationships between parents and its offspring. [9]. The reason for a low heritability is higher contribution of an environmental variance than the contribution of genotypic variance [7]. The scope of heritability including genotypic and phenotypic variability and correlation between different traits of crops have also been notified by many researchers and scientist $[5,11,12]$ for further genetic improvement.
Therefore, the aim of this study was to estimate the genetic correlation and heritability among oilseed cultivars based on morphological attributes to occupy the increasing gap between production and consumption of edible oil.

\section{Materials and methods}

The experiment was carried out to examine genetic correlation and heritability in rapeseed genotypes. The seed of eight rapeseed genotypes was planted in a Randomized Complete Block Design entailing three replications in the experimental field of Oilseeds Section, Agriculture Research Institute, Tandojam during 2017-18. The plot size was put $5 \times 1.35$ meters. The lines of Brassica napus were sown in three rows with the distance of $45 \mathrm{~cm}$ apart from one another. The genotypes of rapeseed were P53-126-140, P-12-R-1, Soomro Road-2, Junica, UCD-320, UCD-5/12, PR-25 and P22.

\section{Statistical analysis}

The collected data were subjected to analysis of variance according to the method developed by [13] Gomes and Gomes (1984). The least significant difference was utilized to compare the values of means at 0.05 probability level according to [14] Steel and Torrie (1984). Simple correlation coefficient (r) was calculated according to the formula given by [15] Snedecor and Cochran (1980) and heritability was calculated with the help of the formula given by [16] Gardener (1961).

$$
\begin{aligned}
& \text { Correlation coefficient }(\mathbf{r})=\frac{\text { Covariance }}{\text { Geometric } \text { mean of covariance }} \\
& \mathrm{r}=\sum \mathrm{xy} \sqrt{\left(\sum \mathrm{x}\right)^{2}-\left(\sum \mathrm{y}\right)^{2}} \\
& \sum \mathrm{xy}=\sum \mathrm{xy} \underset{-\left(\sum \mathrm{x}\right)\left(\sum \mathrm{y}\right)}{\mathrm{N}} \\
& \sum \mathrm{x}^{2}=\sum \mathrm{x}^{2}-\frac{\left(\sum \mathrm{x}\right)^{2}}{\mathrm{~N}} \\
& \sum \mathrm{y}^{2}=\sum \mathrm{y}^{2}-\frac{\left(\sum \mathrm{y}\right)^{2}}{\mathrm{~N}}
\end{aligned}
$$


Heritability $\left(\mathbf{h}^{2}\right)=\frac{V g}{V p} \times 100$

Results

\section{Analysis of variance}

The analysis of variance was found out for the ten growth and yield contributing attributes collected from eight genotypes of rapeseed presented in (Table $1 \& 2$ ). The results regarding analysis of variance in (Table $1 \& 2$ ) revealed that all the characters i.e. plant height $(\mathrm{cm})$, days to $75 \%$ flowering, days to $75 \%$ siliqua formation, number of siliquas (pods) plant $^{-1}$, number of seeds silique ${ }^{-1}$, number of branches plant ${ }^{-1}$, seed yield plant $^{-1}(\mathrm{~g})$, seed index (1000 seed weight, g), oil content (\%), seed yield acre ${ }^{-1}$ $(\mathrm{kg})$ displayed highly significant $(\mathrm{P}<0.01)$ and significant $(\mathrm{P}<0.05)$ differences among the genotypes.

Table 1. Mean squares for different morphological traits of rapeseed genotypes

\begin{tabular}{|c|c|c|c|c|c|c|}
\hline $\begin{array}{c}\text { Source of } \\
\text { variance }\end{array}$ & D. F & $\begin{array}{c}\text { Plant } \\
\text { height } \\
\text { (cm) }\end{array}$ & $\begin{array}{c}\text { Days to } \\
\mathbf{7 5 \%} \\
\text { flowering }\end{array}$ & $\begin{array}{c}\text { Days to } \\
\mathbf{7 5 \%} \\
\text { siliqua } \\
\text { formation }\end{array}$ & $\begin{array}{c}\text { Number of } \\
\text { siliquas } \\
\text { plant }^{-1}\end{array}$ & $\begin{array}{c}\text { Number of } \\
\text { seeds siliqua } \\
1\end{array}$ \\
\hline Replications & 2 & 139.46 & 3.97 & 2.16 & 86614 & 0.13 \\
\hline Genotypes & 7 & $139.48^{* *}$ & $17.61^{* *}$ & $80.83^{* *}$ & $198704^{* *}$ & $0.79^{* *}$ \\
\hline Error & 14 & 62.428 & 1.3631 & 1.9762 & 137628 & 0.21 \\
\hline Total & 23 & - & - & - & - & - \\
\hline
\end{tabular}

Table 2. Mean squares for different morphological traits of rapeseed genotypes

\begin{tabular}{|c|c|c|c|c|c|c|}
\hline $\begin{array}{l}\text { Source of } \\
\text { variance }\end{array}$ & D. F & $\begin{array}{c}\text { Number of } \\
\text { branches }^{-1} \\
\text { plant }^{-1}\end{array}$ & $\begin{array}{l}\text { Seed yield } \\
\text { plant }^{-1}(g)\end{array}$ & $\underset{\text { (g) }}{\text { Seed index }}$ & $\begin{array}{c}\text { Oil content } \\
(\%)\end{array}$ & $\begin{array}{l}\text { Seed yield } \\
\text { acre }^{-1}(\mathrm{~kg})\end{array}$ \\
\hline Replications & 2 & 2.79 & 98.80 & 0.08 & 0.24 & 42205.4 \\
\hline Genotypes & 7 & $2.00 * *$ & 85.21 ** & $1.35^{*}$ & $19.33 * *$ & $45992.0 *$ \\
\hline Error & 14 & 0.34 & 32.00 & 0.69 & 0.07 & 36346.8 \\
\hline Total & 23 & - & - & - & - & - \\
\hline
\end{tabular}

\section{Mean performance}

The results of mean performance for various morphological attributes of rapeseed presented in (Table $3 \& 4$ ) indicated that the variety UCD-5/12 articulated the longest plant with maximum height $(164.40 \mathrm{~cm})$ among all the genotypes followed by P-53$126-140(161.73 \mathrm{~cm})$. For days to $75 \%$ flowering, UCD-5/12 (61.33) ranked the first, while UCD-320 (60.00) ranked the second for the same character. In case of days to $75 \%$ siliqua formation, the maximum value for days $75 \%$ siliqua formation was observed in the variety P-22 (96.66) followed by UCD-5/12 (95.33). However, the highest number of siliquas plant ${ }^{-1}$ was counted in P-53-126-140 (603.10) with the addition of Soomro Road-2 (560.00). For the character number of seeds siliqua ${ }^{-1}$, the variety PR-25 produced a greater number of seeds silique $^{-1}$ (15.90) among all the genotypes with the second position holderUCD-5/12 (15.34). The variety P-53126-140 secured the first position with respect to number of branches plant ${ }^{-1}(9.53)$, but P-22 (9.06) held the second rank for the same trait. Further result articulated that the most seed yield plant $^{-1}(37.28 \mathrm{~g})$ was demonstrated by the variety P-53-126-140, whereas the second rank was taken by variety UCD-5/12 (26.43g). Moreover, PR25 stood on the top in the list in favour of seed index of $5.40 \mathrm{~g}$, nonetheless UCD-320 ranked as the second with the value of 4.65 g. Besides, the results noted for oil content indicated that the variety Soomro Road-2 $(36.37 \%)$ which maintained the highest oil content followed by the variety PR-25 $(36.34 \%)$ oil content and in terms of seed yield acre $^{-1}(\mathrm{~kg})$, the highest seed yield acre 
1 was achieved by P-53-126-140 (871.40

$\mathrm{kg})$, nevertheless UCD-5/12 (763.09 kg)

positioned in the top second of the list.

Table 3. Mean performance of different morphological traits of rapeseed

\begin{tabular}{|c|c|c|c|c|c|}
\hline Genotypes & $\begin{array}{c}\text { Plant } \\
\text { height }(\mathbf{c m})\end{array}$ & $\begin{array}{c}\text { Days to } \\
\mathbf{7 5 \%} \\
\text { flowering }\end{array}$ & $\begin{array}{c}\text { Days to } \\
\mathbf{7 5 \%} \\
\text { siliqua } \\
\text { formation }\end{array}$ & $\begin{array}{c}\text { Number of } \\
\text { siliquas } \\
\text { plant }^{-1}\end{array}$ & $\begin{array}{c}\text { Number of } \\
\text { seeds } \\
\text { siliqua }^{-1}\end{array}$ \\
\hline P-53-126-140 & 161.73 & 55.00 & 84.00 & 603.10 & 15.13 \\
\hline P-12R-1 & 161.47 & 55.66 & 90.66 & 424.50 & 14.56 \\
\hline Soomro Road-2 & 160.27 & 58.00 & 94.66 & 560.00 & 14.41 \\
\hline Junica & 149.40 & 55.33 & 86.66 & 248.10 & 14.70 \\
\hline UCD-320 & 147.40 & 60.00 & 93.00 & 356.50 & 15.28 \\
\hline UCD-5/12 & 164.40 & 61.33 & 95.33 & 369.10 & 15.34 \\
\hline PR-25 & 150.53 & 55.00 & 83.66 & 386.00 & 15.90 \\
\hline P-22 & 150.80 & 57.33 & 96.66 & 341.50 & 14.54 \\
\hline LSD at (5\%) & $\mathbf{2 . 3 4}$ & $\mathbf{3 . 4 6}$ & $\mathbf{2 . 9 0}$ & $\mathbf{5 . 1 6}$ & $\mathbf{0 . 8 9}$ \\
\hline
\end{tabular}

Table 4. Mean performance of different morphological traits of rapeseed

\begin{tabular}{|c|c|c|c|c|c|}
\hline Genotypes & $\begin{array}{c}\text { Number of } \\
\text { branches } \\
\text { plant }^{-1}\end{array}$ & $\begin{array}{l}\text { Seed yield } \\
\text { plant }^{-1}(g)\end{array}$ & $\begin{array}{l}\text { Seed index } \\
\text { (g) }\end{array}$ & $\begin{array}{l}\text { Oil content } \\
(\%)\end{array}$ & $\begin{array}{c}\text { Seed } \\
\text { yield } \\
\text { acre }^{-1} \\
(\mathbf{k g})\end{array}$ \\
\hline P-53-126-140 & 9.53 & 37.28 & 4.58 & 30.36 & 871.40 \\
\hline P-12R-1 & 8.06 & 25.78 & 3.53 & 32.19 & 734.72 \\
\hline Soomro Road-2 & 8.13 & 23.86 & 4.05 & 36.37 & 460.56 \\
\hline Junica & 7.93 & 19.30 & 3.93 & 31.24 & 746.23 \\
\hline UCD-320 & 8.26 & 22.27 & 4.65 & 36.15 & 603.47 \\
\hline UCD-5/12 & 9.00 & 26.43 & 3.51 & 36.15 & 763.09 \\
\hline PR-25 & 8.80 & 25.03 & 5.40 & 36.34 & 746.64 \\
\hline P-22 & 9.06 & 22.75 & 3.58 & 33.18 & 750.16 \\
\hline LSD at (5\%) & 0.78 & 1.22 & 0.35 & 0.45 & 6.33 \\
\hline
\end{tabular}

\section{Correlation coefficient (r)}

\section{Plant height $(\mathbf{c m})$}

Plant height showed highly positive and significant association with only a single attribute that was seed yield plant $^{-1}(\mathrm{r}$ $\left.=46^{* *}\right)$ and affirmative but non-significant correlations with days to $75 \%$ maturity (0.34), days to $75 \%$ siliques formation (0.17), siliques plant ${ }^{-1}$, seeds silique ${ }^{-1}$ (0.17), branches plant ${ }^{-1}(0.31)$, oil content (0.08) and seed yield acre ${ }^{-1}$ (0.05). However, plant height also displayed negative and non-significant with only seed index with the correlation coefficient values of $r=-0.17$.

\section{Days to $75 \%$ flowering}

Days to $75 \%$ flowering was affirmatively significant linked with days to $75 \%$ siliquas formation $\left(\mathrm{r}=66^{* *}\right)$ and oil content $(\mathrm{r}=$ $42 *)$, nevertheless it was non-significantly positive correlated with siliquas plant $^{-1}$ (0.12), branches plant (0.16), seed yield plant $^{-1}(0.14)$. Moreover, negative and nonsignificant associations of days to $75 \%$ flowering were observed with seeds siliqua${ }^{1}$, seed index and seed yield acre ${ }^{-1}$ with the correlation coefficient values of $r=-0.05$, 0.29 and -0.21 .

Days to $75 \%$ siliquas formation

Days to $75 \%$ siliqua formation recorded significant but negative relationships with number of seeds siliqua ${ }^{-1}$ and seed index 
with the association amount value of $\mathrm{r}=$ $0.42^{* *}$ and $-0.63^{* *}$, while it articulated non-significant positive associations with siliquas plant ${ }^{-1}(0.03)$, branches plant $^{-1}$ (0.08) and oil content (0.02).On the contrary, there was non-significant and negative associations of days to $75 \%$ siliquas formation with seed yield plant ${ }^{-1}$ and seed yield acre $^{-1}$ with the correlation coefficient value of $\mathrm{r}=-0.15$ and -0.14 .

Number of siliquas plant ${ }^{-1}$

There existed positive and significant correlation of siliquas plant ${ }^{-1}$ with seed yield plant $^{-1}\left(0.41^{*}\right)$ and significant but negative relationship with seed yield acre ${ }^{-1}$ $\left(-0.65^{* *}\right)$. Moreover, positive and nonsignificant connections of this trait were found with branches plant ${ }^{-1}(0.32)$ and oil content (0.18), yet negative but nonsignificant associations with seeds siliqua ${ }^{-1}$ and seed index with the correlation coefficient value of $\mathrm{r}=-0.18$ and -0.05 .

\section{Number of seeds siliqua ${ }^{-1}$}

The associations of seeds siliqua ${ }^{-1}$ were noted positive and significant with seed yield plant $^{-1}\left(0.38^{*}\right)$, seed index $\left(0.50^{* *}\right)$ and oil content $(0.37 *)$, whereas positive but non-significant correlations of seeds siliqua $^{-1}$ were recorded with branches plant ${ }^{-}$ ${ }^{1}$ and seed yield acre ${ }^{-1}$ with the relationship constant value of $r=0.02$ and 0.33 .

\section{Number of branches plant ${ }^{-1}$}

There was noticed positive and significant association of branches plant ${ }^{-1}$ with seed yield plant ${ }^{-1}\left(0.58^{* *}\right)$, despite the fact that it manifested positive but non-significant correlations with the rest of the attributes such as seed index, oil content and seed yield acre ${ }^{-1}$ with the correlation coefficient value of $r=0.02,0.01$ and 0.09 .

\section{Seed yield plant ${ }^{-1}$}

Seed yield plant $^{-1}$ was only positively as well as non-significantly correlated with all the attributes like seed index (0.18), oil content (0.06) and seed yield acre ${ }^{-1}(0.13)$.

\section{Seed index (1000 grain weight)}

Seed index expressed positive but nonsignificant associations with oil content and seed yield acre ${ }^{-1}$ with the correlation coefficient value of $r=0.32$ and 0.05 .

\section{Oil content (\%)}

There was merely noticed negative and non-significant correlation between oil content and seed yield acre $^{-1}(-0.25)$.

\section{Heritability $\left(\mathbf{h}^{2}\right)$}

The heritability estimates in broad sense, genotypic variance and phenotypic variance from the genetic component variance for different characters studied are depicted in (Table $5 \& 6$ ).

\section{Plant height (cm)}

Plant height manifested that genotypic variance $\left(\sigma^{2} \mathrm{~g}=77.06\right)$ was lower than its phenotypic variance $\left(\sigma^{2} \mathrm{p}=160.29\right)$, which resulted in moderate heritability estimates $\left(\mathrm{h}^{2}=48.07 \%\right)$.

\section{Days to $75 \%$ flowering}

For days to $75 \%$ flowering, the genotypic variance $\left(\sigma^{2} \mathrm{~g}\right)$ and phenotypic variance $\left(\sigma^{2} p\right)$ were 16.25 and 18.07, respectively, which gave high heritability estimates of $89.94 \%$.

\section{Days to $75 \%$ siliqua formation}

In case of days to $75 \%$ siliqua formation, genotypic variance $\left(\sigma^{2} \mathrm{~g}=78.86\right)$ was lower than its phenotypic variance $\left(\sigma^{2} p=81.49\right)$ for resulting in high heritability estimates $\left(h^{2}=96.77 \%\right)$.

Number of siliquas plants ${ }^{-1}$

The genotypic variance $\left(\sigma^{2} \mathrm{~g}=41076.0\right)$ was minutely lower than its phenotypic variance $\left(\sigma^{2} p=251246.67\right)$. Consequently, it revealed higher estimates of heritability $\left(h^{2}=16.35\right)$ for this trait.

\section{Number of seeds siliqua ${ }^{-1}$}

Number of seeds siliqua ${ }^{-1}$ expressed a small difference in genotypic variance $\left(\sigma^{2} \mathrm{~g}=\right.$ $1.79)$ and phenotypic variance $\left(\sigma^{2} p=3.27\right)$, which articulated moderate heritability estimates $\left(h^{2}=54.76 \%\right)$ for this character.

\section{Number of branches plant ${ }^{-1}$}

In terms of branches plant ${ }^{-1}$, the genotypic variance $\left(\sigma^{2} \mathrm{~g}\right)$ and the phenotypic variance $\left(\sigma^{2} p\right)$ was 2.84 and 4.25 respectively, which indicated high heritability estimates $\left(\mathrm{h}^{2}=\right.$ $66.83 \%$ ).

Seed yield plant $^{-1}(\mathrm{~g})$

With respect to seed yield plant $^{-1}$, the genotypic variance $\left(\sigma^{2} \mathrm{~g}\right)$ was 9.15 and phenotypic variance $\left(\sigma^{2} p\right)$ was 142.27, 
which estimated low heritability values $\left(\mathrm{h}^{2}\right.$ $=6.43 \%)$.

\section{Seed index (1000 seed weight, $g$ )}

There was genotypic variance $\left(\sigma^{2} g\right)$ and phenotypic variance $\left(\sigma^{2} p\right)$ with the values of 0.66 and 1.59 for seed index, which displayed moderate heritability $\left(\mathrm{h}^{2}=\right.$ 41.34\%).

\section{Oil content (\%)}

Oil content exhibited the genotypic variance $\left(\sigma^{2} g=19.27\right)$ and phenotypic variance $\left(\sigma^{2} p=19.36\right)$ which demonstrated high heritability $\left(\mathrm{h}^{2}=99.55 \%\right)$.

\section{Seed yield acre ${ }^{-1}$}

In favour of seed yield acre ${ }^{-1}$, the genotypic variance $\left(\sigma^{2} \mathrm{~g}\right)$ was 9645.20 and phenotypic variance $\left(\sigma^{2} \mathrm{p}\right)$ was 58107.60, that maintained low heritability $\left(\mathrm{h}^{2}=16.60 \%\right)$.

\section{Discussion}

Seed yield and oil content are tremendously complex and essential attributes for the crop rapeseed in the breeding of oilseed crops. For such a complexity and essentiality, about linkages of different traits with seed yield, a better explanation is provided by the correlation analysis [17]. Such associations of various attributes are very beneficial for the plant breeders in the selection of those which have a collection of superior characters. In this way, a plant breeder naturally takes a lot of interest in making a discovery of the correlation extent and its types for such attributes [18]. When the all traits are in connection with grain yield, selection is able to make a betterment in the chances of success realizing the motto of a high productivity [19]. In the availability of correlation for the betterment of a quantitative character, heritability also plays a great role as one of the very vital genetic analysis.

The results for analysis of variance (Table $1 \& 2$ ) exposed highly significant and significant differences in the mean squares at $\mathrm{P} \leq 0.01$ and $\mathrm{P} \leq 0.05$ level for all ten quantitative traits, indicating that substantial variability existed in evaluated materials, yet these genetic materials may be preferred for further breeding programs. Our findings were in close agreement with $[20,21]$, who also reported significant variations for a wide range of morphological traits in rapeseed genotypes. The results about the mean performance indicated that variety UCD-5/12 displayed the most marvellous outcomes for plant height and days to $75 \%$ flowering, but the maximum days in the formation of siliquas were observed in the variety P-22. Moreover, the parental line P-53-126-140 performed outstandingly for some most important yield triats which were number of siliques plant ${ }^{-1}$, number of branches plant ${ }^{-1}$, seed yield plant ${ }^{-1}$ and seed yield acre ${ }^{-1}$. The further result showed that best performance for number of seeds silique ${ }^{-1}$, seed index was made by the variety PR-25 and the variety Soomro Road-2functioned superbly for oil content in the experiment. These results were similar to $[22,21]$ as well.

\section{Correlation coefficient (r)}

Plant height showed affirmative, but significant non-significant associations with seed yield plant $^{-1}$ days to $75 \%$ maturity, siliquas plant ${ }^{-1}$, branches plant $^{-1}$ and oil content. Similar results were also observed by [23]. Days to $75 \%$ flowering was affirmatively significant associated with days to $75 \%$ siliqua formation and oil content, however it was non-significantly positive correlated with siliquas plant $^{-1}$, branches plant, seed yield plant ${ }^{-1}$. [24] reported positive and significant associations with all the traits for this trait. Days to $75 \%$ siliqua formation verified significant but negative relationships with seeds siliqua ${ }^{-1}$ and seed index, despite the fact it articulated non-significant affirmative associations with siliquas plant ${ }^{-}$ ${ }^{1}$, branches plant ${ }^{-1}$ and oil content. There existed affirmative and significant correlation of number of siliquas plant $^{-1}$ with seed yield plant $^{-1}$ and significant but negative relationship with seed yield acre ${ }^{-1}$. 
Table 5. Correlation coefficient of different morphological traits of rapeseed

\begin{tabular}{|c|c|c|c|c|c|c|c|c|c|}
\hline Traits & $\begin{array}{l}\text { Plant height } \\
\quad(\mathrm{cm})\end{array}$ & $\begin{array}{c}\text { Days to } 75 \% \\
\text { flowering }\end{array}$ & $\begin{array}{c}\text { Days to } 75 \% \\
\text { siliquas } \\
\text { formation }\end{array}$ & $\begin{array}{l}\text { Numbe } \\
\text { r of } \\
\text { siliquas } \\
\text { plant }^{-1}\end{array}$ & $\begin{array}{c}\text { Number of } \\
\text { seeds } \\
\text { siliqua }^{-1}\end{array}$ & $\begin{array}{c}\text { Number of } \\
\text { branches }^{-1} \\
\text { plant }^{-1}\end{array}$ & $\begin{array}{c}\text { Seed } \\
\text { yield } \\
\text { plant }^{-1}(g)\end{array}$ & $\begin{array}{c}\text { Seed } \\
\text { index } \\
(\mathrm{g})\end{array}$ & $\begin{array}{c}\text { Oil } \\
\text { content } \\
(\%)\end{array}$ \\
\hline Days to $75 \%$ flowering & 0.34 & - & - & - & - & - & - & - & - \\
\hline Days to $75 \%$ siliqua formation & 0.17 & $0.66 * *$ & - & - & - & - & - & - & - \\
\hline Number of siliquas plant ${ }^{-1}$ & 0.29 & 0.12 & 0.03 & - & - & - & - & - & - \\
\hline Number of seeds silique ${ }^{-1}$ & 0.17 & -0.05 & $-0.42 * *$ & -0.18 & - & - & - & - & - \\
\hline Number of branches plant ${ }^{-1}$ & 0.31 & 0.16 & 0.08 & 0.32 & 0.02 & - & - & - & - \\
\hline Seed yield plant $^{-1}$ & $0.46 * *$ & 0.14 & -0.15 & $0.41 *$ & $0.38 *$ & $0.58 * *$ & - & - & - \\
\hline Seed index & -0.17 & -0.29 & $-0.63 * *$ & -0.05 & $0.50 * *$ & 0.02 & 0.18 & - & - \\
\hline Oil content $(\%)$ & 0.08 & $0.42 *$ & 0.02 & 0.18 & $0.37 *$ & 0.01 & 0.06 & 0.32 & - \\
\hline Seed yield acre $^{-1}(\mathrm{~kg})$ & 0.05 & -0.21 & -0.14 & $-0.65 * *$ & 0.33 & 0.09 & 0.13 & 0.05 & -0.25 \\
\hline
\end{tabular}

$*$ = Significant at 0.05 level, $* *=$ Highly significant at 0.01 level, $\mathbf{N S}=$ Non-significant at 0.05 level

Table 6. Heritability estimates in broad sense for various character in rapeseed

\begin{tabular}{|c|c|c|c|}
\hline Traits & Phenotypic variance $\left(\sigma^{2} p\right)$ & Genotypic variance $\left(\sigma^{2} g\right)$ & Heritability $\left(h^{2}\right) \%$ \\
\hline Plant height (cm) & 160.29 & 77.06 & 48.07 \\
\hline Days to $75 \%$ flowering & 18.07 & 16.25 & 89.94 \\
\hline Days to $75 \%$ siliqua formation & 81.49 & 78.86 & 96.77 \\
\hline Number of siliquas plant $^{-1}$ & 251246.67 & 41076.00 & 16.35 \\
\hline Number of seeds siliqua ${ }^{-1}$ & 3.27 & 1.79 & 54.76 \\
\hline Number of branches plant ${ }^{-1}$ & 4.25 & 2.84 & 66.83 \\
\hline Seed yield plant ${ }^{-1}(\mathrm{~g})$ & 142.27 & 9.15 & 6.43 \\
\hline Seed index $(\mathrm{g})$ & 1.59 & 0.66 & 41.34 \\
\hline Oil content $(\%)$ & 19.36 & 19.27 & 99.55 \\
\hline${\text { Seed yield } \text { acre }^{-1}(\mathrm{~kg})}$ & 58107.60 & 9645.20 & 16.60 \\
\hline
\end{tabular}


Moreover, positive and non-significant correlations of this trait were with branches plant $^{-1}$ and oil content. [25] notified about positive and significant correlation between siliquas plant ${ }^{-1}$ and seed yield plant ${ }^{-1}$ in his study. The associations of seed siliqua ${ }^{-1}$ were noted positive and significant with seed yield plant $^{-1}$, seed index and oil content. [26] obtained significantly positive relationship between days to heading and seed yield plant ${ }^{-1}$ and seed index which expressed that high seeds showed was the primary determinant that increased seed yield plant ${ }^{-1}$. There was noticed positive and significant association of number of branches plant ${ }^{-1}$ with seed yield plant $^{-1}$, despite the fact that it manifested positive but non-significant correlations with the rest of the attributes. [27] exhibited the same results as our discovery. Seed yield plant $^{-1}$ was only positively as well as nonsignificantly correlated with all the attributes like seed index, oil content and seed yield acre $^{-1}$. Comparable to our discoveries, [28] detected positive correlation of seed yield with branches plant $^{-1}$ and siliquas plant ${ }^{-1}$ which showed that yield was the primary determinant that increased seed yield plant ${ }^{-1}$ and seed yield acre $^{-1}$ in the coming breeding for oilseed crops. Seed index expressed positive associations with oil content and seed yield acre $^{-1}$. [27] conducted correlation among 13 agronomic characters in 50 genetically diverse genotypes of Brassica napus in which they got significant positive associations with 1000 seed weight. There was merely noticed negative and nonsignificant correlation between oil content and seed yield acre ${ }^{-1}$.

\section{Heritability $\left(\mathrm{h}^{2}\right)$}

Plant height manifested genotypic variance lower than its phenotypic variance resulted in moderate heritability estimates $\left(\mathrm{h}^{2}=\right.$ 48.07\%). [29] determined high broad sense heritability estimates for phenological traits. For days to $75 \%$ flowering, the genotypic variance and phenotypic variance were very equal for each other and presented high heritability estimates of
89.94\%. [21] unveiled the highest heritability for this trait. In case of days to $75 \%$ siliqua formation, genotypic variance was lower than its phenotypic variance for resulting in high heritability estimates $\left(\mathrm{h}^{2}=\right.$ $96.77 \%$ ). There were discovered moderate to high values for heritability in broad sense in magnitude for all traits in the experiment of [20]. The genotypic variance for number of siliquas plant ${ }^{-1}$ was minutely lower to its phenotypic variance which revealed low heritability estimates $\left(h^{2}=16.35\right)$. [30] expressed the highest genotypic and phenotypic variances for siliquas plant ${ }^{\mathbf{1}}$. Number of seeds silique ${ }^{-1}$ articulated a very less alteration in the genotypic and phenotypic variance in the display of moderated heritability values $\left(h^{2}=54.76 \%\right)$ for this character. With respect to branches plant $^{-1}$, the genotypic variance and the phenotypic variance maintained high heritability estimates $\left(h^{2}=66.83 \%\right)$. With respect to seed yield plant $^{-1}$, the genotypic variance and phenotypic variance estimated low heritability values $\left(h^{2}=6.43 \%\right)$. There was displayed moderate heritability $\left(\mathrm{h}^{2}=\right.$ $41.34 \%$ ) for seed index due to the contribution of genotypic and phenotypic variances. Oil content exhibited good results for genotypic variance and phenotypic variance that demonstrated high heritability $\left(\mathrm{h}^{2}=99.55 \%\right)$. [22] observed the maximum heritability in broad sense for oil content in his research. In favour of seed yield acre $^{-1}$, the genotypic variance and phenotypic variance kept low heritability $\left(\mathrm{h}^{2}=16.60 \%\right)$.

\section{Conclusion}

Seeds plant ${ }^{-1}$ was variable with the greatest potentiality of selection for seed yield betterment as these possessed superior outcomes for correlation and heritability in the investigation of something new in the crop rapeseed which will be very advantageous for the upcoming breeding development.

\section{Authors' contributions}

Conceived and designed the experiments: M Baloch \& K Laghari, Performed the experiments: K Laghari, KK Menghwar, M 
Kachi \& WH Shah, Analyzed the data: JK Sootaher, ZM Kambher \& I Daudpotto, Wrote the paper: JK Sootaher \& MK Soother.

\section{Reference}

1. Fekri, MS, MA Samih, S. Imani \& M Zarabi (2013). Study of host preference and the comparison of some biological characteristics of Bemisiatabasi on mustard varieties. J Plant Prot Res 53(2): 47-52.

2. Prakash, S \& K Hinata (1980). Polyphyletic origins of Brassica napus: new evidence based on organelle and nuclear RFLP analysis. Genome 35: 992-1001.

3. Tiwari, DD, SB. Pandey \& MK. Dubey (2012). Effect of potassium application on yield and quality characteristics of pigeon pea and mustard crops in central plain zone of Uttar Pradesh. Int Potash Inst 31: 16-20.

4. GOP (2017). Economic Survey of Pakistan, 2016-17. Ministry of Food, Agriculture, Finance Division, Economic Advisor's Wing, Islamabad, Pakistan.

5. Ali, N, F Javidfar \& AA Attary (2002). Genetic variability, correlation and path analysis of yield and its components in winter rapeseed (Brassica napus L.). Pak J Bot 34(2): 145-150.

6. Shahid, M, M Fida \& M Tahir (2002). Path coefficient analysis in wheat. Sarhad J Agric 18: 383-388.

7. Aycecik, M \& T Yildirim (2006). Heritability of yield and some yield components in bread wheat (Triticum aestivum L.) genotypes. Bangladesh J Bot 35(1): 17-22.

8. Raj, A, V Oudenaarden \& A Alexander (2008). Nature, nurture, or chance: Stochastic gene expression and its consequences. Cell 135(2): 216-226.

9. Rajper, MM, BA Ansari \& AJ Malik (1996). Heritability of grain yield and yields related characters of $\mathrm{F}_{4}$ population of wheat (Triticum aestivum L.). Pak J Agric Engg Vet Sci 12(1-2): 9-14.
10. Gielen, M, PJ. Lindsey, C Derom, HJM Smeets, NY Souren, ADC Paulussen, $R$ Derom \& JG Nijhuis (2008). Modeling genetic and environmental factors to increase heritability and ease the identification of candidate genes for birth weight. Behav Genet 38(45): 44-54.

11. Lekh, R, S. Hari VP Singh, L Raj \& H Singh (1998). Variability studies in rapeseed and mustard. Ann Agric Res 19(1): 87-88.

12. Saini, HP \& Sharma (1995). Model plant architecture through association and path coefficient analysis in Indian colza. Ind J Agric Res 29: 109-115.

13. Gomez, KA \& AA Gomez (1984). Statistical procedures for agricultural research. John Wiley \& Sons Inc., 2nd (ed.) New York, U.S.A.

14. Steel, RGD \& JH Torrie (1984) Principles and Procedures of Statistics: A Biometrical Approach. 2nd McGraw Hill Book Co., Singapore.

15. Snedecor, GW \& WG Cochran (1980). Statistical Methods. 7th Edition, Iowa State University Press, Ames. USA.

16. Gardener, CO (1961). An evaluation of effects of mass selection and seed irradiation with thermal neutrons on yield of corn. Crop Sci 1: 241-245.

17. Dixet, P \& DK Dubey (1984). Path analysis in lentil (Lens culinaris L.). Lens Newsletter 11: 15-17.

18. Zafarnaderi, N, S Aharizad \& SA Mohammadi (2013). Relationship between grain yield and related agronomic traits in bread wheat recombinant inbred lines under water deficit condition. Ann Biol Res 4(4): 711.

19. Uddin, F, F Mohammad \& S Ahmed (2015). Genetic divergence in wheat recombinant Inbred lines for yield and yield components. J Agric Environ Sci 15(9): 1854-1859.

20. Bilal, M, SA Khan, H Raza, F Ali, SM Khan, N Ali, I Hussain \& J Khan (2015). Evaluation of some indigenous rapeseed genotypes for adaptability 
and yield traits in the agro-climatic conditions of Mansehra. Int J Biosci 7(5): 127-135.

21. Rubby-Sandhu, SKR, R Bharti, A Kour, SK Gupta \& A verma (2017). Studies on genetic diversity among various genotypes of rapeseed (Brassica napus L.) using morphological markers. Int J Curr Microbiol App Sci 6(7): 469-480.

22. Fakharuddin, NU Ullah, Raziuddin, I Ullah, MM Ul-Haq, Ataullah, MJ Razi, Qamaruddin \& S Ahmed (2016). Genetic variability, correlations and heritability estimates for various biochemical traits in rapeseed (Brassica napus L.). AmericanEurasian J Agric Environ Sci 16(3): 594-597.

23. Ejaz-Ul-Hasan, HSB Mustafa, T Bibi \& $\mathrm{T}$ Mahmood (2014). Genetic variability, correlation and path analysis in advanced lines of rapeseed (Brassica napus L.) for yield components. Cercet Agron Mold 1(157): 71-79.

24. Meena, ML, RB. Ram, R Lata \& SR Sharma (2009). Determining yield components in cabbage (Brassica oleracea L.) through correlation and path analysis. Int J Sci Nat 1(1): 27-30.
25. Abideen, SNU, $F$ Nadeem \& SA Abideen (2013). Genetic variability and correlation studies in rapeseed (Brassica napus L.) genotypes”. Int J Inn Appl Studies 2(4): 574-581.

26. Guang, LU, F Zhang and $P$ Zheng (2011). Relationship among yield components and selection criteria for yield improvement in early rapeseed. (Brassica napus L.). J Int Agric 10(7): 997-1003.

27. Poorva, S, SP Singh \& ID Pandey (2001). Character association and path analysis in Brassica species L. Indian J. Agric. Res 35(1): 63-65.

28. Malik, MA, AS Khan, Shafiullah \& MK Ayub (2000). Study of correlation among morphological parameters in different varieties of Brassica species. Pak J Bio Sci 3(7): 1180-1182.

29. Rameeh, V (2015). Heritability, genetic variability and correlation analysis of some important agronomic traits in rapeseed advanced lines. Cercet Agron Mold 4(64): 165-169.

30. Ali, N, F Javaidfar, JY Elmira \& MY Mirza (2003). Relationship among yield components and selection criteria for yield improvement in winter rapeseed (Brassica napus L.). Pak J Bot 35(2): 167-174. 